\title{
Changes in suspension properties of structural modified montmorillonites
}

\section{(Mudanças em propriedades de suspensões de montmorilonitas modificadas estruturalmente)}

\author{
C.Volzone, L. B. Garrido \\ CETMIC \\ Centro de Tecnología de Recursos Minerales y Cerámica; CONICET-CIC-UNLP \\ C. C. 49. Cno. Centenario y 506 (1897) M. B. Gonnet, Prov. Buenos Aires, Argentina \\ fax: +54-221-4710075, volzcris@netverk.com.ar
}

\begin{abstract}
Rheological changes were found in smectite (Wyoming- and Cheto-type montmorillonites) suspensions after structural modifications. The effect of the particle size and $\mathrm{Na}^{+}$ exchange on the flow curves of $6 \% \mathrm{wt} / \mathrm{wt}$ suspensions of smectites with and without $\mathrm{Na}_{2} \mathrm{CO}_{3}$ were examined. Mineralogical, structural and physicochemical characteristics were studied by X-ray diffraction (XRD), infrared spectroscopy (IR), cationic exchange capacity (CEC), $\mathrm{Mg}^{2+}$, $\mathrm{Al}^{3+}$ determinations, particle size distribution and swelling index (SI). Grinding in an oscillating mill modified the particle sizes. The montmorillonite grain size and the structural disorder increased after larger grinding times. The grinding treatment modified the apparent viscosity and the yield stress of the montmorillonite suspensions. The homoionic $\mathrm{Na}$ Cheto-type montmorillonite with fine particle size (obtained by grinding) increased the flow properties. Nevertheless, rheological properties were lower than those of suspensions of the Wyoming-type montmorillonite. Montmorillonite-types reacted differently with $\mathrm{Na}_{2} \mathrm{CO}_{3}$ additions and this behavior may be related to their structural composition. The $\mathrm{Na}_{2} \mathrm{CO}_{3}$ activation improved the flow properties of the original Wyoming-type montmorillonite and after $30 \mathrm{~s}$ grinding.
\end{abstract}

Keywords: smectites, montmorillonite suspensions, rheology.

\section{INTRODUCTION}

Aqueous bentonite suspensions are widely used in industrial processes because they exhibit properties of thixotropic gels.

The bentonite is a rock essentially composed of smectite. The smectites are clays, which are classified, as 2:1 phyllosilicates constitute by an octahedral layer containing $\mathrm{Al}$ or $\mathrm{Mg}$ ions between two tetrahedral silica layers. The montmorillonite is one species of the dioctahedral smectites. Grim and Kulbicki [1] proposed that the montmorillonite may be subdivided into Cheto- and Wyoming-types according to the

\section{Resumo}

Foram encontradas mudanças reológicas em suspensões de esmectitas (montmorillonitas tipos Wyoming e Cheto) após modificações estruturais. Foi examinado o efeito do tamanho de partícula e troca de $\mathrm{Na}^{+}$nas curvas de escoamento de suspensões de esmectitas $6 \%$ peso com e sem $\mathrm{Na}_{2} \mathrm{CO}_{3}$. As características mineralógicas, estructurais e fisico-quimicas foram estudadas por difração de raios X(DRX), espectroscopia no infravermelho (IV), capacidade de troca catiônica (CTC), determinações de $\mathrm{Mg}^{2+}$ e $\mathrm{Al}^{3+}$, de distribuição de tamanho de partículas e de indice de expansão (swelling index - SI). Moagem em moinho oscilatório modificou o tamanho das partículas. O tamanho de grão da montmorillonita e a desordem estrutural aumentaram após maiores tempos de moagem. O tratamento por moagem modificou a viscosidade aparente e o limite de escoamento das suspensões de montmorillonita. A montmorillonita homoiônica de Na do tipo Cheto com pequeno tamanho de particula (obtido por moagem) melhorou as propriedades de escoamento. Entretanto, as propriedades reológicas foram piores que as de suspensões de montmorillonita do tipo Wyoming. Os diferentes tipos de montmorillonitas reagiram de modo diferente com adições de $\mathrm{Na}_{2} \mathrm{CO}_{3}$ e este comportamento pode estar relacionado com suas composições estruturais. A ativação por $\mathrm{Na}_{2} \mathrm{CO}_{3}$ melhorou as propriedades de escoamento da montmorillonita tipo Wyoming original após moagem por $30 \mathrm{~s}$.

Palavras-chave: esmectitas, suspensões de montmorillonita, reologia.
$\mathrm{Mg}^{2+}$ content in octahedral layer with higher content in the Cheto-type. In previous papers it was observed that mineralogical composition, the percentage of fine particles and $\mathrm{Na}^{+}$content of the raw materials are the principal factors to be considered in rheological properties [2]. The Wyoming-type montmorillonite suspensions with much fine particles content and high percentage of exchangeable $\mathrm{Na}^{+}$show higher viscosity values, yield stress and thixotropy than the Cheto-type montmorillonite suspension. The last type has thickness particles and high $\mathrm{Ca}^{2+}$ content as exchangeable cation.

The aim of this paper is to modify the structural and physical 
characteristics of two different type montmorillonites and to analyze the rheological properties of the aqueous suspensions with and without $\mathrm{Na}_{2} \mathrm{CO}_{3}$ previous treatment.

\section{MATERIALS AND METHODS}

The raw materials used in this study were: $\mathrm{SA}_{\mathrm{z}-1}, \mathrm{Ca}$ montmorillonite, USA; $\mathrm{SW}_{\mathrm{y}-1}$, Na montmorillonite, USA; and two commercially available smectitic materials (bentonites) CO and DG from Argentina. $\mathrm{SA}_{\mathrm{z}-1}$ and $\mathrm{CO}$ are Cheto-type whereas $\mathrm{SW}_{\mathrm{y}-1}$ and DG are Wyoming-type montmorillonites [2].

The homoionic $\mathrm{SA}_{\mathrm{z}-1}-\mathrm{Na}$ was prepared by saturation with $2 \mathrm{~N}$ $\mathrm{NaCl}$ aqueous solutions and subsequent washings to eliminate residual $\mathrm{Cl}^{-}$.

Mineralogical compositions of the montmorillonites were investigated by X-ray diffraction (XRD). A Phillips PW 1140 device at $40 \mathrm{kV}$ and $20 \mathrm{~mA}$ with $\mathrm{Cu}$ radiation $(\mathrm{K} \alpha=0.154 \mathrm{~nm})$ and $\mathrm{Ni}$ filter was used. The samples were analyzed by XRD powder in aggregate and oriented slides form.

Infrared spectrometry (IR) was obtained with a Perkin-Elmer 577 spectrometer. The samples were diluted in $\mathrm{KBr}$ and compacted to form thin pellets.

The cation exchange capacity (CEC) was determined using $2 \mathrm{~N}$ ammonium acetate at $\mathrm{pH}=8$. Exchangeable cations $\left(\mathrm{Na}^{+}, \mathrm{K}^{+}, \mathrm{Ca}^{2+}\right.$, $\mathrm{Mg}^{2+}$ ) were measured by atomic emission and absorption analysis.

The structural composition was derived from chemical analysis on the basis of anion charge of $\mathrm{O}_{10}(\mathrm{OH})_{2}$ per half-unit formula.

Particle size distribution was obtained using Sedigraph 5000D equipment.

The particle sizes were modified by grinding in an oscillating mill (Herzog HSM 100) with a rotative frequency of $12.5 \mathrm{sec}^{-1}$ during measured times. The resulting materials were identified as $\mathrm{B} / \mathrm{T}$, where $\mathrm{B}$ was the $\mathrm{SA}_{\mathrm{z}-1} \mathrm{Na}, \mathrm{SW}_{\mathrm{y}-1}$, CO or DG samples and $\mathrm{T}$ was the grinding time: $0,30,60$ or 300 seconds.

The swelling index (SI) was measured by adding of $2.00 \mathrm{~g}$ of dry material to $100 \mathrm{~cm}^{3}$ of distilled water.

Montmorillonites were saturated with $\mathrm{Na}_{2} \mathrm{CO}_{3}$ by adding the solution to dry materials $(\leq 74 \mu \mathrm{m})$ at room temperature. This treatment was carried out using a saturated solution of $\mathrm{Na}_{2} \mathrm{CO}_{3}$ $\left(20 \mathrm{~g} / 100 \mathrm{~cm}^{3} \mathrm{H}_{2} \mathrm{O}\right.$ ) in a proportion of $100 \mathrm{meq} / 100 \mathrm{~g}$ sample. The mixture was homogenized and left standing for 24 hours. The wet $\mathrm{Na}_{2} \mathrm{CO}_{3}$-treated material was dispersed in water for obtaining a suspension of $6 \% \mathrm{wt} / \mathrm{wt}$.

Rheological measurements were carried out using a Haake RV3 viscometer with a system of rotating concentric cylinder MVIP at $25{ }^{\circ} \mathrm{C}$. Flow curves were obtained from suspensions of original montmorillonites and after treatment with $\mathrm{Na}_{2} \mathrm{CO}_{3}$.

\section{RESULTS AND DISCUSSION}

The process of grinding to modify particle size produced additional structural and physicochemical changes.

Fig. 1 shows the granulometry distribution of the montmorillonites after different grinding times. Particle size distributions of $\mathrm{SW}_{\mathrm{y}-1}, \mathrm{SW}_{\mathrm{y}-1} / 30$, DG and DG/30 samples were not possible to obtain by using the same analyzer (the small particles were hydrated and produced the gelation of suspensions preventing the particle sedimentation). The percentage of fine particles of Cheto-type montmorillonites $\left(\mathrm{SA}_{\mathrm{z}-1}\right.$ and $\mathrm{CO}$ ) increased after $30 \mathrm{~s}$ grinding. All samples showed thickness size ( $\mathrm{D}_{50}$ close to $\left.10 \mu \mathrm{m}\right)$ after $300 \mathrm{~s}$ of grinding. Such behavior could be attributed to aggregate particles [3].

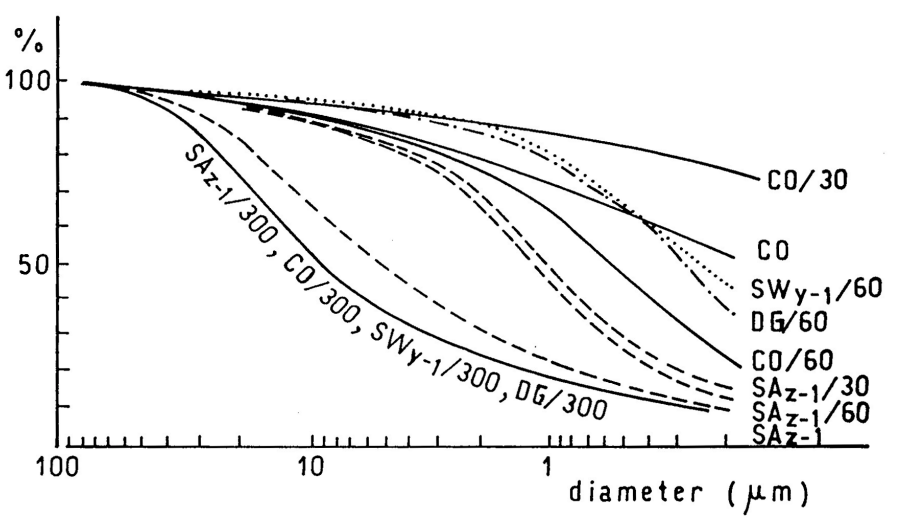

Figure 1: Particle size distribution of montmorillonite samples.

In smectites, the colloidal fraction of a distribution contributes to increase the specific surface area and to provide gel structure due to attractive/repulsive forces acting on colloid particles. Therefore, the submicron size content is related to swelling index. Wyoming-type montmorillonites ( $\mathrm{SW}_{\mathrm{y}-1}$ and $\mathrm{DG}$ ) showed higher swelling index (SI) than the Cheto-type $\mathrm{SA}_{\mathrm{z}-1}^{\mathrm{y}-1}$ and $\mathrm{CO}$ as shown Fig. 2.

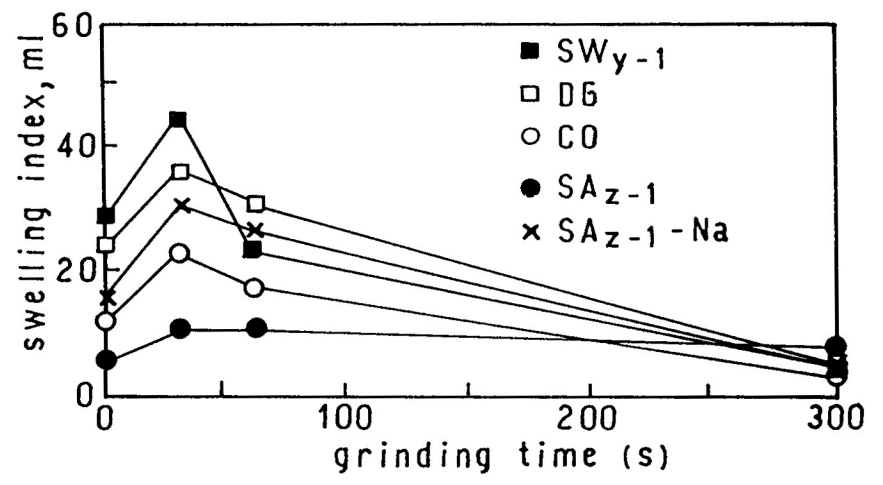

Figure 2: Swelling index vs. grinding time.

The exchange with $\mathrm{NaCl}$ in the $\mathrm{SA}_{\mathrm{z}-1}\left(\mathrm{SA}_{\mathrm{z}-1}-\mathrm{Na}\right)$ improved the degree of hydration of the clay and thereby increasing SI but the values were lower than Wyoming-types montmorillonites. SI of samples increased with grinding time (30 s), Fig. 2. Physical sorption of water occurs because the increase in colloidal content of smectites favors the adsorption phenomenon. The swelling index (SI) decreased when the samples were ground for larger times because produced a re-aggregation of material and then water retention was smaller.

Fig. 3 shows the d(001) spacing after K-saturation and glycol treatment, in powder aggregate and oriented specimen of the $\mathrm{CO}$ and DG samples in original and after grinding conditions. $\mathrm{SA}_{\mathrm{z}-1}$ and $\mathrm{SW}_{\mathrm{y}-1}$ were analyzed in previous work [4]. The behavior of $\mathrm{CO}$ and $\mathrm{DG}$ samples was similar to that of the $\mathrm{SA}_{\mathrm{z}-1}$ and the $\mathrm{SW}_{\mathrm{y}-1}$, respectively, which are characteristics of Cheto and Wyoming type montmorillonites. The Cheto-type montmorillonite expand about $1.5 \mathrm{~nm}$ whereas Wyoming-type expands about $1.7 \mathrm{~nm}$ after treatment with KCl-ethylene-glycol solvated [1]. Then, CO and DG samples 


\section{CO DG}
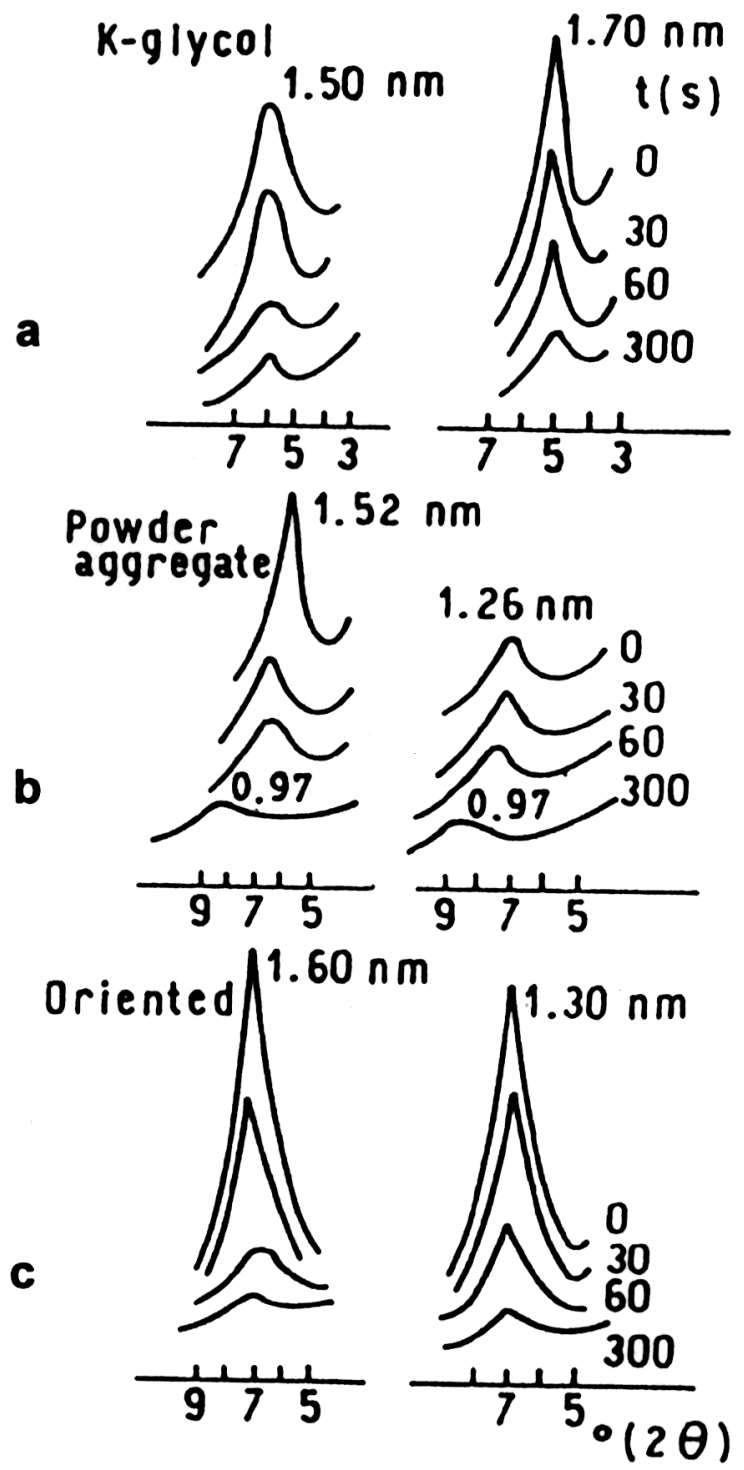

Figure 3: d(001) spacing of CO and DG samples after grinding. a: K-glycol treatment in oriented conditions; b: powder aggregate; $c$ : in oriented conditions.

showed Cheto- and Wyoming-type montmorillonites, respectively (Fig. 3a) and such characteristics were maintained during all grinding times. The XRD peaks of the ground samples were lower in intensity and became broader than the original samples. Lattice strain and small crystallite size could contribute in broadening of the X-ray diffraction patterns [5]. The diffractograms in powder aggregates conditions (Fig. 3b) of the ground samples at $300 \mathrm{~s}$, showed a decrease in the $\mathrm{d}(001)$ spacing, indicating a collapse of the structure $(0.97 \mathrm{~nm})$. This collapse was reversible because XRD of samples in oriented conditions (after rehydration) maintained the same value than original samples (1.30-1.60 nm for each montmorillonites type) but with lower intensity (Fig. 3c). This degree of reversibility evidenced that the samples exhibited a similar behavior than after thermal treatment at low temperature, $200{ }^{\circ} \mathrm{C}[4]$

The total XRD diagram of samples in powder aggregates showed higher loss of crystallinity of the Wyoming-types ( $\mathrm{SW}_{\mathrm{y}-1}$ and DG) than the Cheto-types $\left(\mathrm{SA}_{\mathrm{z}-1}\right.$ and $\left.\mathrm{CO}\right)$ when the samples were ground $300 \mathrm{~s}$ (not shown).
The crystalline alteration of the 2:1 phyllosilicates produced by mechanical treatment depends mainly of mill used. In previous studies of grinding with clay materials and using planetary ball mill, were shown that after a period of 30-60 minutes the $h \mathrm{kl}$ reflection had decreased [5-7] whereas using an oscillating mill [8,9] such time is reduced.

Fig. 4 shows the infrared spectra of $\mathrm{SW}_{\mathrm{y}-1}$ and $\mathrm{SA}_{\mathrm{z}-1}$ (Wyomingand Cheto-types, respectively) in original and ground $300 \mathrm{~s}$ conditions. The bands centered at $3640 \mathrm{~cm}^{-1}(\mathrm{OH}), 915 \mathrm{~cm}^{-1}\left(\mathrm{Al}_{2} \mathrm{OH}\right)$ and $840 \mathrm{~cm}^{-1}(\mathrm{Mg}-\mathrm{Al}-\mathrm{OH})$ were more alterated than the $1025 \mathrm{~cm}^{-1}$
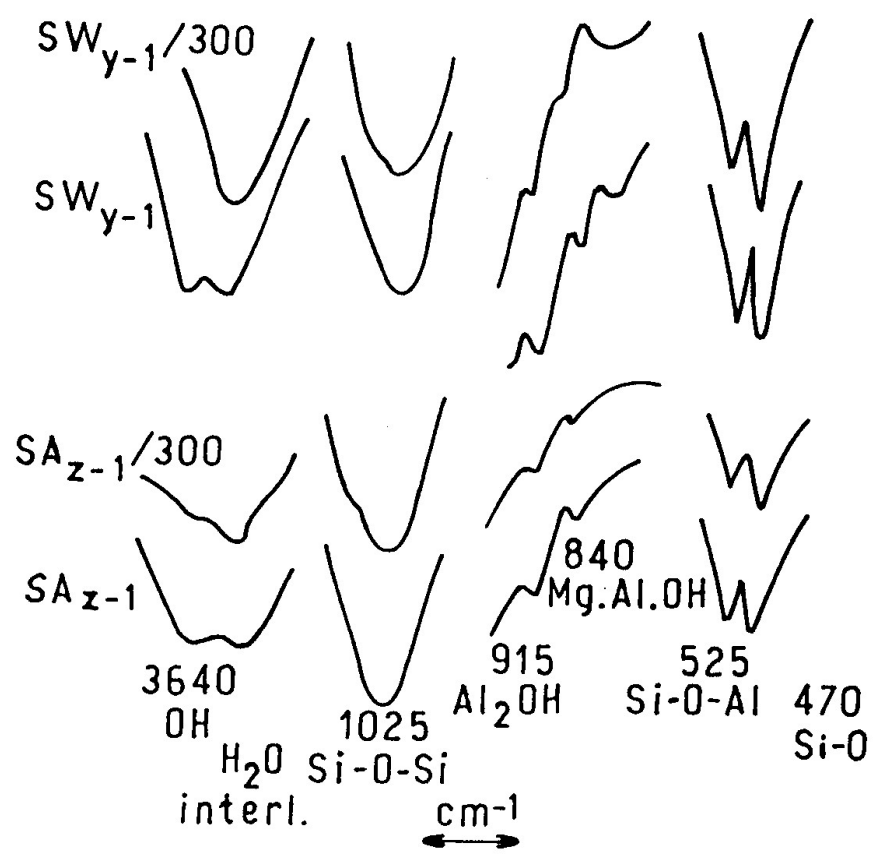

Figure 4: IR spectra of the original and modified $\mathrm{SW}_{\mathrm{y}-1}$ and $\mathrm{SA}_{\mathrm{z}-1}$ montmorillonites.

(Si-O), $525 \mathrm{~cm}^{-1}$ (Si-O-Al) and $470 \mathrm{~cm}^{-1}$ (Si-O) after $300 \mathrm{~s}$ of grinding time. These band modifications may be explained by Al$\mathrm{Mg}$ migration to the surface. Smectite after a prolonged grinding (780 s) shows an IR spectrum similar to that of silica gel [9].

Breakdown of the layer increases of exposed functional group $\mathrm{AlOH}, \mathrm{SiOH}, \mathrm{SiOAl}$ and the cation exchange capacity could be

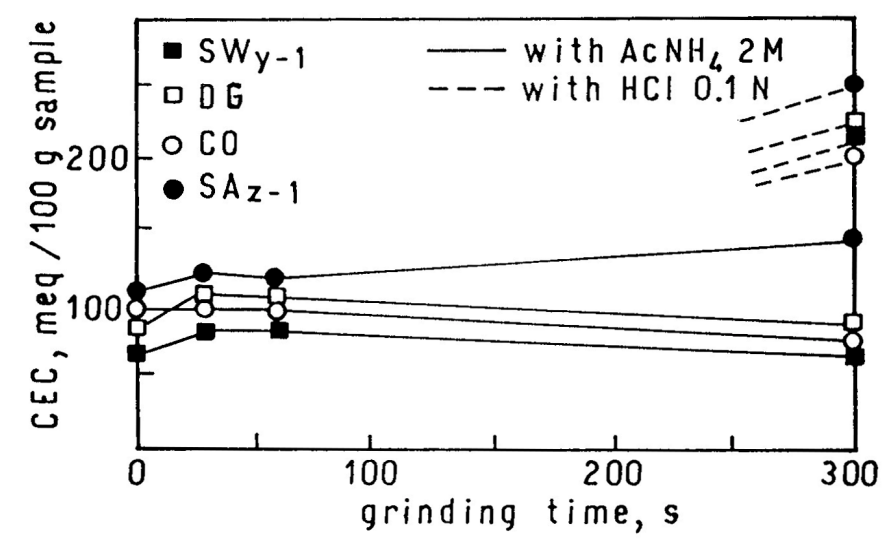

Figure 5: Cation exchange capacity of the different montmorillonites. 
increased [3]. Fig. 5 shows the CEC of the samples determinated with ammonium acetate. The aluminum migration from the structure was not detected in such solutions. Probably the aluminum was polymerized and strongly adsorbed on the clay surface. To confirm aluminum migration, the sample was washed with $0.1 \mathrm{~N} \mathrm{HCl}$ solution and $\mathrm{Al}$ release was colorimetrically determined by the Aluminon method. Fig. 5 also shows the CEC calculated by adding the amount of the aluminum extracted from the ground sample during $300 \mathrm{~s}$.

Fig. 6 shows the amounts of $\mathrm{Mg}^{2+}$ and $\mathrm{Al}^{3+}$ removed from montmorillonite structure after grinding. The amount of cations removed may be indicative of the proportion structure damage by grinding. Higher amount of $\mathrm{Mg}^{2+}$ was extracted for Cheto-type montmorillonites ( $\mathrm{SA}_{z-1}$ and $\mathrm{CO}$ ) than Wyoming-types ( $\mathrm{SW}_{\mathrm{y}-1}$ and DG) after grinding. Whereas higher $\mathrm{Al}^{3+}$ was extracted from Wyoming-types. This observation was in according to the structural composition (Table I).

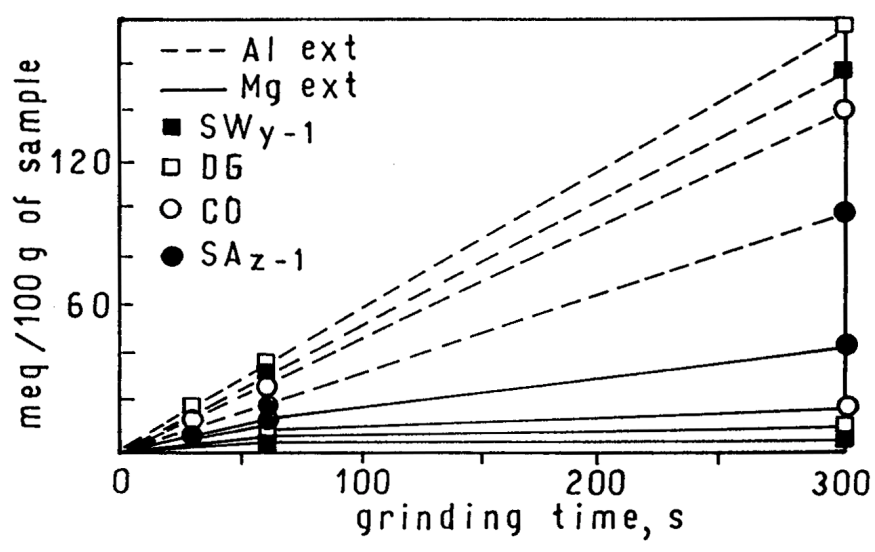

Figure 6: $\mathrm{Mg}^{2+}$ and $\mathrm{Al}^{3+}$ extracted from the structure after grinding.

The octahedral $\mathrm{Mg}^{2+}$ content in $\mathrm{SA}_{\mathrm{z}-1}$ and $\mathrm{CO}$ samples correspond to the range of Cheto-type [1]. Table I shows that the octahedral sheet of the Cheto-type has greater $\mathrm{Mg}^{2+}$ content than that of the Wyoming-type, in which octahedral $\mathrm{Al}^{3+}$ content is higher. The sum of $\mathrm{Mg}$ and $\mathrm{Al}$ extracted from the structure after $300 \mathrm{~s}$ of grinding in all samples was around $30 \%$ of the original content

Table I - Structural formulae of Cheto- and Wyoming-type montmorillonites.

\begin{tabular}{ccccc}
\hline & \multicolumn{2}{c}{ CHE TO-TYPE } & \multicolumn{2}{c}{ WYOMING-TYPE } \\
& $\mathrm{SA}_{\mathrm{z}-1}$ & $\mathrm{CO}$ & $\mathrm{SW}_{\mathrm{y}-1}$ & $\mathrm{DG}$ \\
\hline $\mathrm{Si}_{\text {tet }}$ & 3.93 & 3.89 & 3.92 & 3.93 \\
\hline $\mathrm{Al}_{\text {tet }}$ & 0.07 & 0.11 & 0.08 & 0.07 \\
\hline $\mathrm{Al}_{\text {oct }}$ & 1.40 & 1.44 & 1.61 & 1.50 \\
\hline $\mathrm{Fe}_{\text {oct }}$ & 0.10 & 0.09 & 0.13 & 0.19 \\
\hline $\mathrm{Mg}_{\text {oct }}$ & 0.50 & 0.47 & 0.20 & 0.29 \\
\hline $\begin{array}{c}\mathrm{Mg}+\mathrm{Al} \\
\text { removed after } \\
\begin{array}{c}300 \mathrm{~s} \text { of } \\
\text { grinding }(\%)\end{array}\end{array}$ & 28 & 29 & 29 & 32 \\
\hline
\end{tabular}

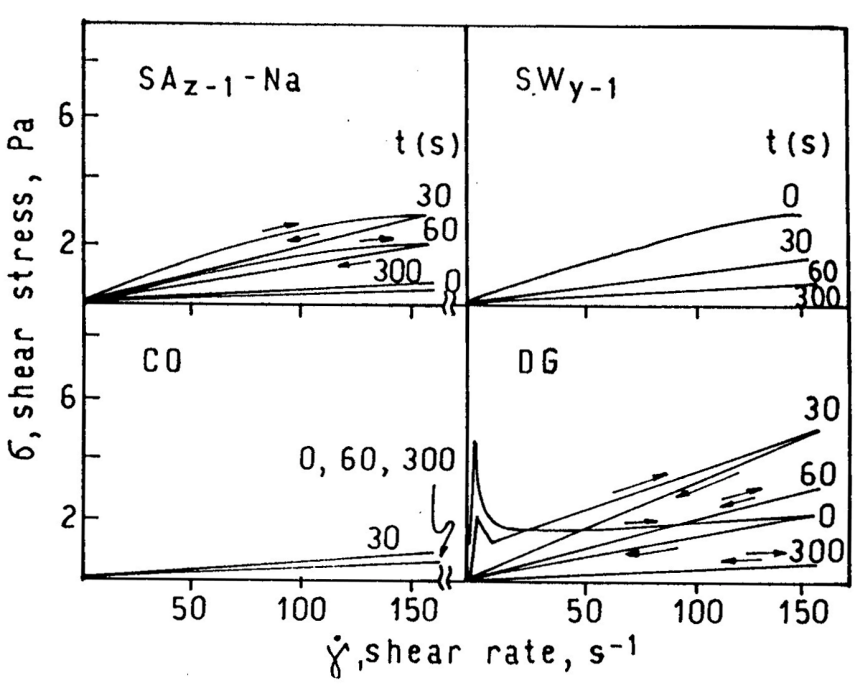

Figure 7: Flow curves of $6 \% \mathrm{wt} / \mathrm{wt}$ aqueous suspensions of the natural and modified Cheto-type ( $\mathrm{SA}_{\mathrm{z}-1}-\mathrm{Na}$ and $\left.\mathrm{CO}\right)$ and Wyoming-type $\left(\mathrm{SW}_{\mathrm{y}-1}\right.$ and $\left.\mathrm{DG}\right)$ montmorillonites.

Fig. 7 shows flow curves of the original smectites after different grinding times. The curve of original $\mathrm{SA}_{\mathrm{z}-1}$ sample was not shown because it was similar to that of CO suspension. Suspensions of the original $\mathrm{CO}$ and $\mathrm{SA}_{\mathrm{z}-1}-\mathrm{Na}$ samples had a low apparent viscosity, which is the shear stress to shear ratio at constant shear rate, and Newtonian behavior. The $\mathrm{SW}_{\mathrm{y}-1}$ suspension is characterized by higher viscosity values and a slight shear thinning behavior (apparent viscosity slightly decreased with increasing shear rate). DG suspension showed a complex non-Newtonian behavior exhibiting high viscosity values, hysteresis loop and a high initial shear stress peak that may be associated with the existence of a gel network. This hysteresis loop is related to gel destruction in small aggregates due to the shear flow.

The exchange with $\mathrm{Na}^{+}$, and increase in fine particles obtained after short grinding time improved the rheological properties of the $\mathrm{SA}_{z-1}$ sample (Cheto-type) suspension. However, the values of the rheological properties obtained are lower than that of the original Wyoming-type. The $\mathrm{SA}_{\mathrm{z}-1}-\mathrm{Na} / 30$ and $\mathrm{SA}_{\mathrm{z}-1}-\mathrm{Na} / 60$ suspensions showed also a hysteresis loop. The grinding did not improve the flow behavior of $\mathrm{SW}_{\mathrm{y}-1}$ suspension. The rheological properties of the DG/30 suspension were increased. The higher exchangeable $\mathrm{Na}^{+}$content in DG $(66 \%)$ than the $\mathrm{SW}_{\mathrm{y}-1}(52 \%)$ could be related with different behavior among Wyoming-types [2]. Large grinding times originated significant changes in rheological properties that may be attributed to thickness particles and the loss of crystallinity. Aggregation in thick particles reduced the viscosity.

Fig. 8 shows flow curves of the montmorillonite suspensions after sodium carbonate treatment. Na activation was not always effective.

The flow curve of the homoionic $\mathrm{SA}_{\mathrm{z}-1} \mathrm{Na} / 30$ suspension treated with $\mathrm{Na}_{2} \mathrm{CO}_{3}$ (Fig. 8) was lower than that of the original suspension (Fig. 7). Probably the increase in sodium concentration produced flocculation of clay particles due to diffuse double layer compression and could be responsible of the reduction in rheological properties [10]. For the suspensions of $\mathrm{SW}_{\mathrm{y}-1}$ and $\mathrm{SW}_{\mathrm{y}-1} / 30$ the curves describe a complex non-Newtonian behavior showing high viscosity values, extrapolated yield stress and hysteresis loop. Therefore, these systems are characterized by a shear thinning and tixotropic 


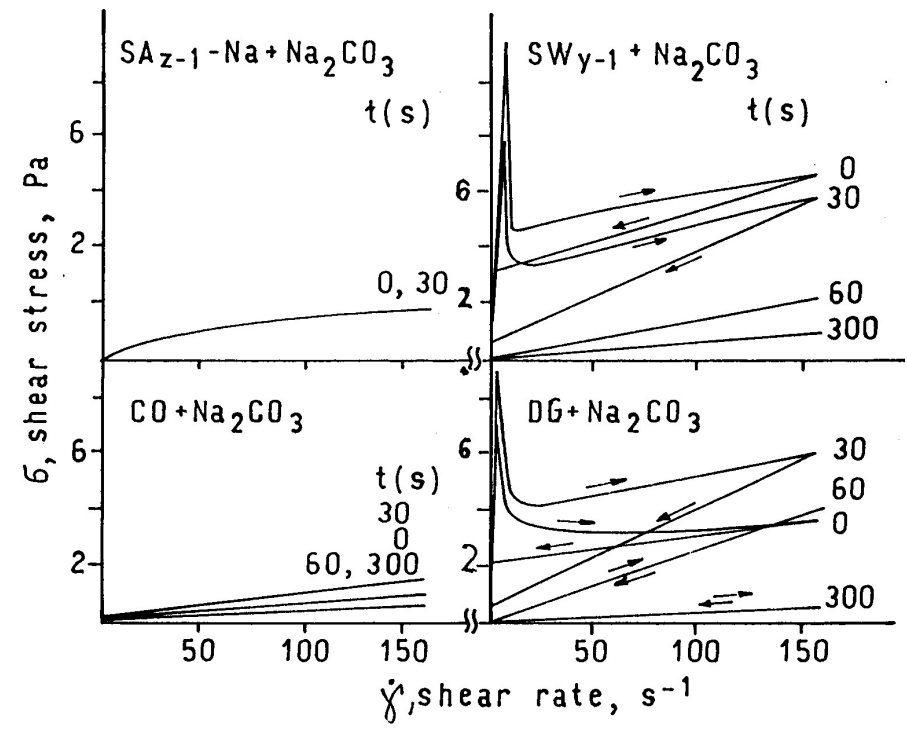

Figure 8: Flow curves of $6 \% \mathrm{wt} / \mathrm{wt}$ aqueous suspensions of Cheto- and Wyomingtype montmorillonites treated with $\mathrm{Na}_{2} \mathrm{CO}_{3}$

behavior. The increase in viscosity was mainly caused by the delamination of the particles due to $\mathrm{Na}^{+}$exchange in an alkaline medium. Moreover, according to Brandenburg and Lagaly [11], the presence of $\mathrm{Ca}^{2+}$ ions on the smectite surface promotes the formation of a band type structure among fine aggregates of sodic smectite. At high $\mathrm{pH}$, the band-like structure produces an increase in viscosity.

\section{CONCLUSIONS}

The structural characteristics are important factors to be considered in suspension properties of the montmorillonites.

Homoionic $\mathrm{Na}$ Cheto-type montmorillonite having fine size of particles (obtained by grinding) increased the flow properties. Nevertheless, these flow properties were lower than that of suspensions of Wyoming-type montmorillonite. Both types of montmorillonites reacted differently with $\mathrm{Na}_{2} \mathrm{CO}_{3}$. The high layer charge of Cheto-type montmorillonite $\left(\mathrm{Al}^{3+}\right.$ substituted by $\mathrm{Mg}^{2+}$ in octahedral sheet) and interlayer $\mathrm{Ca}^{2+}$ reduce osmotic swelling and delamination of particles in alcaline media.

Addition of $\mathrm{Na}_{2} \mathrm{CO}_{3}$ improved the flow properties of the Wyoming-type montmorillonite suspensions and it appears to be enhanced when the samples were ground for short times as the content of fine particles increases. In addition to aggregation of the particles, large grinding times originated damage of the structure on the bentonite, interlayer collapse and $\mathrm{Al}-\mathrm{Mg}$ remotion from octahedral sheet of near $30 \%$. Nevertheless, the characteristic type of montmorillonite remaining in the ground sample was preserved and the interlayer collapse was reversible after rehydration. Aggregation in thick particles reduced suspension viscosity.

\section{REFERENCES}

[1] R. E. Grim, G. Kulbicki, Am. Mineral. 46 (1961) 1329.

[2] C. Volzone, L. B. Garrido, Appl.Clay Sci. 6 (1991) 143.

[3] S. Yariv, H. Cross, in Geochemistry of Colloid Systems for Earth Scientists, Springer-Verlag, Berlin, Heidelberg New York (1979) 450. [4] C. Volzone, L. B. Garrido, in Mineral Processing and Environmental, IV Meeting of the Southern on Mineral Technology, Ed. S. Castro and F. Concha, Universidad de Concepción, Chile, I (1994) 179-187.

[5] P. J. Sánchez-Soto, M. Macías, J. L. Pérez-Rodríguez, J. Am. Ceram. Soc. 76 (1993) 180.

[6] J. P. Sánchez-Soto, A. Justo, A. Ruíz-Conde, M. A. Avilés, J. L. Pérez-Rodríguez, Third Euro-Ceramics, 2 (1994) 985.

[7] U. Mingelgrin, L. Kliger, M. Gal, S. Saltzman, Clays \& Clay Miner. 26 (1978) 299.

[8] E. F. Aglietti, J. M. Porto López, E. Pereira, Int. J. Miner. Process. 16 (1986) 125.

[9] C. Volzone, E. F. Aglietti, A. N. Scian, J. M. Porto López, Appl.Clay Sci. 2 (1987) 97.

[10] G. Lagaly, Appl. Clay Sci. 4 (1989) 105.

[11] U. Brandenburg, G. Lagaly, Appl. Clay Sci. 3 (1983) 263.

(Rec. 14/07/00, Rev. 24/10/00, Ac. 02/02/01) 